\title{
Sociologie religieuse et sociologie fonctionnelle
}

\section{Henri Desroche}

\section{(c) OpenEdition \\ Journals}

\section{Édition électronique}

URL : http://journals.openedition.org/assr/24537

ISSN : $1777-5825$

Éditeur

Éditions de l'EHESS

Référence électronique

Henri Desroche, "Sociologie religieuse et sociologie fonctionnelle », Archives de sciences sociales des religions [En ligne], L'héritage des Formes, mis en ligne le 12 mars 2013, consulté le 26 avril 2019. URL: http://journals.openedition.org/assr/24537

Ce document a été généré automatiquement le 26 avril 2019.

(C) Archives de sciences sociales des religions 


\title{
Sociologie religieuse et sociologie fonctionnelle
}

\author{
Henri Desroche
}

NOTE DE L'ÉDITEUR

Ce texte est disponible sur Persée 